\title{
Corporate Governance as a Tool for Curbing Bank Distress in Nigeria Deposit Money Banks: Empirical Evidence
}

\author{
IKPEFAN, OCHEI AILEMEN Ph.D (Banking \& Finance), ACA, ACIB \\ Senior Lecturer, Department of Banking \& Finance, Covenant University, Ota, Ogun State \\ E-mail Ochei_Ikpefan@yahoo.Co.Uk \\ OJEKA, S.A (M.Sc Accounting) \\ Department of Accounting, Covenant University, Ota, Ogun State \\ E-mail stojeka@yahoo.com
}

\begin{abstract}
Objective The study objective is aimed at finding the relationship between corporate governance bank distress in deposit money banks. The research design adopted in this paper is the case study method, in other to have an intensive insight of the subject matter. Methodology Primary data was used specifically the survey technique. The method that was used in the presentation of data in this study is the Statistical Package for Social Sciences (SPSS) which contains all the necessary and important statistical technique for data analysis.Findings For testing the hypothesis, correlation analysis which measures the degree of relationship between variables was used to analyze the result generated from the questionnaire. The evidence shows that corporate governance has no significant improvement on the prevention of bank distress but has significantly improved the performance of the Nigerian banking sector. Recommendation We therefore recommend that banks should demonstrate strong internal policies to identify and manage conflict of interest and zero tolerance posture against cases of unsound corporate governance practices.
\end{abstract}

Type of Paper: Case Study

Key words: Corporate Governance, Bank Distress, Code of Conduct, Pearson Correlation

\subsection{INTRODUCTION}

The Organization of Economic Corporation and development (OECD, 2004) defines corporate governance as involving "a set of relationships between a company's management, its board, its shareholders, and other stakeholders. Corporate governance also provides the structure through which the objectives of the company are set, and the means of attaining those objectives and monitoring performance are determined. Good corporate governance should provide proper incentives for the board and management to pursue objectives that are in the interests of the company and shareholders and should facilitate effective monitoring, thereby encouraging firms to use resources more efficiently". Corporate governance in recent years assumed considerable significance as a veritable tool for ensuring corporate survival since business confidence usually suffers each time a corporate entity collapses. Most of the business failures in recent past are attributed to failure in corporate governance practices. For instance, the collapse of banks in Nigeria in the early 1990's and onwards was as a result of inadequate corporate governance practices such as insider-related credit abuses and poor risk appreciation and internal control system failure.

Corporate governance refers to the organizational framework for decision making and action taking within a corporate entity. In this regard, it can also be defined as the structure of relationships within an entity for making decisions and implementations. Simply put, it refers to how an organization is run, that is, how the resources of an organization are employed in pursuant of the set missions and goals of the organization. Hussey (1999) as cited in Ivior (2008) defines corporate governance more formally as "the manner in which organizations, particularly limited companies, are managed and the nature of accountability of the managers to the owners". In other words, corporate governance is not just a set of rules but also a structure of relationships geared towards establishing good corporate practice and culture. The ultimate Business Dictionary (2003) as cited in Sani (2010) defines corporate governance functionally as the managerial or directional control of an incorporated organization, which, when well practiced can reduce the risk of fraud, improve company performance and leadership and demonstrate social responsibility. Essentially, corporate governance is focused on controlling the activities of those in whose custody the resources of an organization are entrusted with a view to protecting the interest of the resource owners.

Wise and MahboobAli (2009) opined that "corporate governance indicates the policies and procedures applied by firms to attain certain sets of objectives, corporate missions and visions with regard to stockholders, employees, customers, suppliers and different regulatory agencies and the community at large". Effective corporate governance practices are essential to achieving and maintaining public trust and confidence in the banking system, which are critical to the functioning of the banking sector and economy as a whole. Poor corporate governance may contribute to bank failures, which can pose significant public costs and consequences 
due to inability of a bank to manage its assets and liabilities, including deposits, lost of confidence and in turn trigger a bank run or liquidity crisis.

Oyediran (2003) as cited in Babalola (2010) posits that corporate governance is the way and manner in which the affairs of companies are conducted by those charged with that duty. In Nigeria, the governance of a limited liability company is the responsibility of its board of directors. Corporate governance is characterized by transparency, accountability, probity and the protection of stakeholders' rights. Corporate governance refers to the manner in which the power of a corporation is exercised in the management of its total portfolio of economic and socio resources with the aim of increasing shareholders' value and safeguarding the interest of other stakeholders in the content of its corporate mission.

The above definitions are summarized into one by the Report of the Committee on Corporate Governance of Public Companies in Nigeria (2003) as cited in Sani (2010) which sees corporate governance as "the system by which companies in Nigeria are directed, and managers are held accountable for the performance of the organization." This further emphasizes the fact that the concept of corporate governance is principally on the structure of relationship within an organization which is directed at best practice in the overall interest of the organization and its owners/stakeholders with the sole aim of curbing distress in the Nigeria banking system.

In ordinary parlance, distress connotes being in danger or difficulty and in need of help. A bank is distressed when it is technically insolvent implying that the bank's liabilities exceed the assets. The terms distress connotes "unhealthy situation" or a state of inability or weakness, which prevents the achievement of set goals and aspiration (Ologun, 1994). Benston et al, (1986) as cited in Sani (2010) defines distress as a situation of complete loss of shareholder funds. To evolve a working definition of distress, it is desirable to synthesize those factors that will the unhealthy as well as state some broad set obligation and aspiration of a typical financial institution. A financial institution is described as unhealthy, if it is unable to meet its obligation to owners and the economy occasioned by severe financial, operational and managerial weaknesses (Ologun, 1994). To Elebuta (1999), distress occurs when a fairly reasonable proportion of banks in the banking sector are unable to meet their obligation to customers, owners and the economy, as a result of weakness in the financial, operational and managerial capabilities which renders them either illiquid or insolvent.

The Nigerian banking sector witnessed dramatic growth post -consolidation. Banks began to grow in size and numbers and even diversified across the shores of the country with branches and subsidiaries. However, neither the industry nor the regulators were sufficiently prepared to sustain and monitor the sector's explosive growth. Prevailing sentiments and economic orthodoxy all encouraged this rapid growth, creating a blind spot to risks building up in the system. Prior to the crisis, the sentiment in the industry was that the banking sector was sound and growth should be encouraged. The international monetary fund (IMF) endorsed the strength of the banking system to support this growth. However, this sentiment proved misplaced. Among the many interdependent factors that led to creation of an extremely fragile financial system is failure in corporate governance at banks. Consolidation created bigger banks but failed to overcome the fundamental weaknesses in corporate governance in many of these banks.

The problem in the Nigerian banking industry pre-post consolidation has been that of risk management arising from accumulation of huge non-performing accounts. This is as result of non-application of the five ' $\mathrm{C}$ ' of lending - Character, Capacity, Capital, Condition and Collateral. The banking industry experienced misuse of shareholders funds, governance malpractice, unchecked at consolidation. For instance, a large part of the sector enriched themselves at the expense of many depositors and investors. Corporate governance in many banks failed because boards ignored governance practices to the extent executive management obtained for themselves un-secured loans at the expense of the depositors and they did not have the boldness to enforce good governance. In addition, the audit process at all banks appeared not to have taken fully into account the rapid deterioration of the economy and hence the need for aggressive provisioning against risk and assets.

As banks grew in size and complexity, bank boards often did not fulfill their function and were lulled into a sense of well-being by the apparent year-over-year growth in assets and profits. In hindsight, boards and executive management in some major bank were not equipped to run their institutions. The bank chairman/CEO often had an overbearing influence on the board, and some boards lacked independence; directors often fail to make meaningful contributions to safe guard the growth and development of the bank and had weak ethical standards: the board committees were also often ineffective or dormant. Chief executive officers (CEO's) lend money to themselves for stock price manipulation and other activities in variance with corporate governance. A review of the prevailing situation in the Nigerian banking industry shows that most banks are yet to embrace practices that will ensure good corporate governance in their institutions. Good governance practices results in higher firm's market value, lower cost of funds and higher profitability (Black, Jang \& Kin, 2006 \& Claessens, 2006).

According to Chiejina (2009), "the executive of banks had abandoned the key elements of good corporate principles of honesty, trust, and integrity, openness, performance orientation, responsibility and accountability, 
mutual respect and commitment to the organization for selfish reasons". The core banking practices have been traded off and the most beneficial are the CEOs and their loyalist. Eight chief executives and executive directors of some Nigerian banks were dismissed between August and October 2009 due to issues related to poor corporate governance practices. This was the outcome of audit investigations embarked upon by the Central Bank of Nigeria to determine the soundness of Nigerian banks. Hence, this paper is poised to examine the role of corporate governance practice in relation to bank distress in Nigerian deposit money banks (formerly known as commercial banks). It is also aimed at finding the relationship between good governance and better performance of banks. Based on the objectives and focus of this study the hypotheses formulated were:

$\mathrm{H}_{1}$ : There is no significant relationship between good corporate governance and prevention of bank distress

$\mathrm{H}_{2}$ : There is a significant relationship between practice of good corporate governance and better performance of banks.

It is pertinent to note that the understanding of corporate governance will increase growth rate, increase efficiency of their activities and minimize risks, improve standard of lending, strengthen their reputation and raise the level of investors and clients trust and attract strategic investors. The remainder of this paper proceeds as follows. In section two a review of relevant literature in the area of corporate governance and distress is examined. In section three, an explanation of the methodology is provided. The empirical evidence of this paper is discussed in section four. Lastly, the paper ends conclusion and recommendation.

\subsection{REVIEW OF RELATED LITERATURE}

Inyang (2009) conclude in his findings on nurturing corporate governance system: emerging trends in Nigeria, concluded that major challenges which require urgent attention to enhance the effectiveness of the system were noted "making voluntary codes mandatory; developing more effective mechanisms for monitoring compliance and enforcement; developing strong internal control mechanisms to checkmate the boards oversight responsibility; crafting strategies to enhance shareholders activism and the extension of the codes to state-owned enterprises with more cases of corporate abuses". The SEC Code of Best Practice for Public Companies in Nigeria is voluntary and is designed to entrench good business practices and standards for all listed companies, including banks. The mandatory corporate governance provisions relating to banks are contained in the Companies and Allied Matters Act (CAMA) 1990, the Banks and other Financial Institutions Act (BOFIA) 1999, the investments and Securities Act 1999.The Securities and Exchange Commission Act (SECA) 1988 (and its accompanying Rules and Regulations, the Code of Conduct for Directors of licensed Banks and Financial Institutions (approved by the Bankers' Committee in 2003) and Code of Corporate Governance for Banks in Nigeria Post Consolidation issued by $\mathrm{CBN}$ in 2006. Compliance with the provisions of these codes is compulsory.

The impetus for the development of corporate governance system in Nigeria also came through the activities of the Nigeria Securities and Exchange Commission (SEC). In 2001, the SEC set up the Atedo Peterside committee to identify weaknesses in the current corporate governance practices in Nigeria with respect to public companies and make recommendations on the necessary changes therein. A Code of Best Practices for Public companies in Nigeria was adopted (SEC, 2003).The code is voluntary and is designed to entrench good business practices and standards for boards and directors, CEOs, auditors, etc., of listed companies, including banks.

A major development in the history of corporate governance in Nigeria is the recent intervention by the Central Bank of Nigeria $(\mathrm{CBN})$. The incessant collapse experienced in the banking sector due to poor corporate governance and the recent bank consolidation exercise forced the $\mathrm{CBN}$ to issue new corporate governance guidelines to all banks operating in the country in Febraury 2006. Known as Central Bank of Nigeria Code for Corporate Governance for Banks in Nigeria Post Consolidation (CBN, 2006), the code seeks to address the issues of poor corporate governance and create a sound banking system in Nigeria. The code introduced more stringent requirements in the area of industry transparency, equity ownership, criteria for the appointment of directors, board structure and composition, accounting and auditing, risk management and financial reporting. The new code according to $\mathrm{CBN}$ was developed to complement existing codes in the country, and compliance to it is mandatory for all banks

Earlier studies by Okike (1994, 1995, 1998 and 1999) specifically investigated the accounting and auditreporting environment in Nigeria, as important elements of corporate governance. Okike (2007), posited that the role of the Corporate Affairs Commission (CAC) has remained perfunctory and ineffective as some companies and even auditors are known to have flouted company legislation without being punished. In their review of corporate governance in Africa, Okeahalam and Akinboade's (2003) conclude that "the adoption of corporate governance principles by African countries will be a giant step towards creating safeguards against corruption and mismanagement, promote transparency in economic life and attracting more domestic and foreign investment". Ogbechie and Koufopoulos (2007) evaluated corporate governance issues in public quoted companies in Nigeria. The findings of the study show that Nigeria public companies have embraced the 
principles of good governance but at different stages of adoption of various issues that contribute to good governance. Oyejide and Soyibo (2010) suggest that for Nigeria to reap the benefits of effective corporate governance there is need to strengthen the enforcement mechanism of the regulatory institutions. The role of the Court is important in this regard. The judicial system must have the capacity to restore the confidence of the shareholders and help him to enforce his rights.

Shah and Haq (2007) undertook an empirical study and found that:

"in the cement sector of Pakistan, corporate governance structure variables such as percentage block holding by individual and family members, board size and firm size have a positive impact on firm performance. They concluded that the firm's performance is adversely affected if the CEO also acts as chairperson of the board of directors; the percentage of blocking holdings by financial institutions has a negative relationship with performance; the size of the firm has a positive impact on firm performance and the expected leverage is an adverse signal for firm performance"

Before the consolidation exercise of 2006, the Nigerian banks were very weak with poor corporate governance, and this affected customers' confidence in banking operations. The consolidation exercise helped to reduce the total numbers of deposit money banks from 89 to 25 and to 19 in 2012 (excluding the three nationalized banks Enterprise, keystone and mainstream banks) through mergers and acquisitions and consolidations. This development posed serious challenges which the $\mathrm{CBN}$ has acknowledged in its Code of Corporate Governance (CBN, 2006).

"These challenges include technical incompetence of board management; Boardroom squabbles among directors; Squabbles among staff and management; very few banks have a robust risk management system; malpractices and sharp practices; insider abuses; rendering false returns and concealment of information from examiners; ineffectiveness of board/statutory committees and inadequate operational and financial controls".

All existing banks in the country are required by the code to adopt and enforce well articulated codes of ethics and conduct for directors, management and staff and to render periodic report (Templars, 2006). The key highlights of the Codes of corporate governance of SEC and CBN include:

Separating the roles of the CEO and board Chairman; prescription of non-executive and executive directors on the board; Improving the quality and performance of board membership; Introducing merit as criteria to hold top management position; introducing transparency, due process and disclosure requirements; transparency on financial and non-financial reporting; protection of shareholder rights and privileges; and defining the composition, role and duties of the audit committee, etc (Wilson,2006).

However deliberate accounting fraud is serious problem of corporate governance in the country. Cases of "inaccurate reporting and non-compliance with regulatory requirement" (Ibru, 2008) and "the prevailing incidences of false and misleading financial reporting" (Al-faki,2007) by some corporate organizations lead to corporate failures. We have different shareholders associations registered with Corporate Affairs Commission (CAC). Etukudo (2000) argued that the shareholder associations serve the interest of the investing public as shareholders who have the opportunity to contribute to the formulation of broad corporate policies, thereby enhancing management accountability. However, for effective performance of this body, corporate governance institutions need to strengthen shareholders activism as a prerequisite for effective corporate governance and accountability in Nigeria. In Nigeria, there is the general weakness of public institutions, high level of corruption, poor managerial capacity and total absence of market discipline for transparency and accountability, which combine to create a seeming lack of demand for corporate governance in state-owned enterprises (Ahmed, 2007).

The corporate governance framework also depends on the legal, regulatory, and institutional environment. In addition factors such as business ethics and corporate awareness of the environmental and societal interest of the communities in which a company operates will also have an impact on its reputation and its long term success.

\section{Key element of a sound corporate governance framework in a bank}

Hennie and Sonja (2009) expressly state the main elements of corporate governance in a bank to include the following:

- A well articulated corporate strategy against which the overall success and the contributions of individuals can be measured;

- Setting and enforcing clear assignment of responsibilities, decision making authority, and accountabilities appropriate for banks selected risk profile;

- Strong financial risk management function (independent of business lines), adequate internal control systems (including internal and external audit functions), and functional process design with the necessary checks and balances;

- Adequate corporate values, codes of conduct, and other standards of appropriate behavior and effective system used to ensure compliance. This includes special monitoring of the bank's risk exposure where conflict of interests is expected to appear (example relationship with affiliated parties). 
- Financial and managerial incentives to act in an appropriate manner offered to the board, management, and employees, including compensation, promotion, and penalties (compensation should be consistent with the banks objectives, performance and ethical values).

- Transparency and appropriate information flows internally to the public.

According to CBN (2006), "No one person should combine the post of Chairman/Chief Executive Officer of any bank". No two members of the same extended family should occupy the position of Chairman and that of Chief Executive Officer or Executive Director of a bank at the same time. The office of the Chief Executive should be held by a different person other than the chairman. This is because such step could lead to the problem of moral hazard and thereby threatening the financial sector stability. Effective corporate governance is all about board's performance. The task of growing a corporate entity is the work of board of directors. For a board to function effectively, it should be composed of members who are independent, skilled, knowledgeable, experienced and of diverse perspectives. In Nigeria there has been a high profile case of corporate failure which is traceable to weak and ineffective boards. In some cases, the board appear were dormant being satisfied with having business cards that identify them as board members. Critical reviews of the nation's banking system over the years have shown that one of the problems confronting the sector had been that of poor corporate governance. From the closing reports of banks liquidated between 1994 and 2003, there were evidences that clearly established that poor corporate governance led to their failures. A further revelation showed that many owners and directors abused or misused their privileged positions or breached their fiduciary duties by engaging in self serving activities. The abuses included granting of unsecured credit facilities to owners, directors and related companies which in some cases were in excess of their banks statutory lending limits in violation of the provisions of the law.

Sanusi (2010) contends that the primary responsibility of keeping individual bank sound lies with each banks owner, managers, and the board of directors. Together, they must establish a framework of internal controls and practices to govern the operations of the bank and ensure that it functions in a safe and sound manner. Poor internal governance has been identified as a major factor in virtually all known instances of banking unsoundness. One basic requirement is that persons who control and manage the business of banking must be men of integrity, above board, trustworthy and must possess appropriate skills and experience.

Sanusi (2010), posits that disclosure and transparency are key pillars of a corporate governance frame work, because they provide all the stakeholders with the information necessary to judge whether or not their interest are being served. He sees transparency and disclosure as an important adjunct to the supervisory process as they facilitate banking sector market discipline. For transparency to be meaningful, information should be accessible, timely, relevant and qualitative. According to Anameje (2007) as cited in Babalola (2010), transparency and disclosure of information are key attributes of good corporate governance which banks must cultivate with new zeal so as to provide stakeholders with the necessary information to judge whether their interest are being taken care of. Sanusi (2003) opines that lack of transparency undermines the ethics of good corporate governance and the prospect for effective contingency plan for managing systemic distress.

There are various laws put together to regulate the practice of a particular trade or profession in order to protect investors and ensure a stable business environment and to prevent distress, which in this case concerns the banking industry. They are CBN act (1991), Bank and Other Financial Institution Act (BOFIA) 1991 as amended, Investment and Securities Act (ISA) 1999, The Nigerian Deposit Insurance Corporations Act (NDIC) 1988 as amended and other laws. However the basic laws governing all companies operating in Nigeria is the Companies and Allied Matters Act (CAMA) 1990. The act makes it mandatory that all companies operating in Nigeria must be registered either as a private company or as a public company limited by shares. The provisions of the CAMA also require that the financial statements of each company should conform to the accounting standards. Specific standards for reporting consolidated accounts regarding all or any of the subsidiaries of the company must be specified and applied as detailed by Unegbu (2003).

In Nigeria, the insider's trading, massive and prevalent frauds, mandatory retirement of CEOs of banks, due to corrupt practices and inefficient rubber-stamped board, have combined to signal the absence of or failure of existing corporate governance structure. The Company and Allied Matters Act (CAMA) enacted to regulate and balance the relationship among the board, shareholders and the management including other stakeholders, failed woefully due to inadequate enforcement capacity.

\section{Challenges and Failures of Corporate Governance in Nigeria}

The challenges and failure of corporate governance in Nigeria stems from the culture of corruption and lack of institutional capacity to implement the codes of conduct governing corporate governance. Company executives enjoy an atmosphere of lack of check and balances in the system to engage in gross misconducts since investors are not included in the governing structure. Policy and procedures required to ensure efficient internal controls are disregarded, and total lack of thorough selection process (of CEO and board members - round pegs in square holes) remain a challenge in Nigeria. The businesses cum shareholders' interests are secondary to the self- 
interest of board members and the management. Limited opportunities for institutional investors, and near zero interest in corporate social investments to demonstrate companies' sense of belongingness as evidenced in environmental pollutions, are clear indications of failure of corporate governance. Lack of managerial training and capacity development among Nigerian executives to manage business risks has resulted in huge agency costs, and shareholders have had to shoulder several avoidable agency costs since the board of directors usually failed as a monitoring device to minimize agency problems.

The recent collapse of The Nigerian Stock Exchange market is a pointer to a system devoid of controls and accountability, which resulted in lack of shareholders' interest and confidence in the operating environment. Some Nigerian companies relocated their operations to more stable and vibrant neighboring countries like Ghana and South Africa. Failure of corporate governance in Nigeria has also been traced to lack of effective yardsticks to evaluate board and management processes and performance, since the board sub-committees required to be fully independence, especially the audit and remuneration committees, are compromised. The auditors/the audit committee of the board have been singled out as instrument of fraudulent practices given their readiness to cover-up corrupt practices for executives in a desperate bid for kick-back, and, to retain the audit engagement(s) of big clients (Habeeb, 2010). According to the code of corporate governance issued by CBN (2006), the following are challenges that are faced by consolidated banks in respect to the adherence to the code.

Technical incompetence of board and management: in view of the greatly enhanced resources of the consolidated entities, board members may lack the requisite skills and competences to effectively redefine, restrategize, restructure, expand and or refocus the enlarged entities in the areas of change of corporate entities new business acquisitions, branch consolidation, expansion and product development.

Relationship among directors: boardroom squabbles could be an issue due to different business cultures and high ownership concentration especially in banks that were formerly "one-man" entities. The dominance of a "key man" could also emerge with the attendant problems.

Increased level of risks: currently, very few banks have a robust risk management system in place. With the huge amount of funds that will be available to them and the significantly increased legal lending limits, banks will be financing more long term mega projects in the real sectors of the economy as opposed to the existing working capital/trade financing. Given the expected significant increase in the level of operation, the banks will be facing various kinds of risks which, if not well managed, will result in significant losses. The management of risks in a transparent and ethical way will thus present some issues bordering on corporate governance.

Resurgence of high level malpractices: to boost income as a result of intense competition and lack of enough viable projects, malpractices may resurface post consolidation. Such sharp practices could include round tripping of forex, excessive customer charges, falsification of records etc, and adoption of unethical methods to poach customers.

The corporate failures which characterized 2000 to 2002 when institutions like Enron and WorldCom collapsed brought corporate governance issues to the front burner. Arunma (2010) stated thus that "corporate failures no doubt drew the world's attention to the fact that good corporate governance was extremely important to corporate performance and survival; indeed there is a nexus between good corporate governance and the preservation of shareholders value, safeguarding investors' assets and promoting financial stability particularly, when governance of financial institutions is concerned. Indeed good corporate governance has become an important index for institutional investors' participation in business enterprises and financial markets".

\subsection{METHODOLOGY}

Participants and Procedures: The sample of study consisted of 120 respondents who were mainly bank employees amongst who are professional experts and investment analysts, shareholders and customers among others. The choice of respondents was based on their knowledge and experience in the industry. Ninety respondents finally participated in the study, which represented $75 \%$ response rare. Among the respondents,46(51.1\%) represents male and 44(48.9\%) represents female. Majority of the respondent are in the middle age which is between 31 to 40 years (58\%) have been working with the organization for more than 5 years and $32 \%$ have been working between 5-10years.Majority of the respondent have First degree (57\%), while those with Masters Degree are $20 \%$ and only $23 \%$ with diploma qualification.

Research Instruments: The research design adopted in this study is the case study method, in other to have an intensive insight of the subject matter. Primary data used is the survey technique. This was supplemented with data from secondary sources of information. The research was carried out in the Nigeria banking industry based on a sample of four deposit money banks (formerly called commercial banks) in Nigeria. Out of the One hundred (120) questionnaires that were administered on the 4 deposit money banks, (30 questionnaire each for the 4 different banks) only 90 questionnaires were retrieved. The research work was designed in such a way that data was generated from the questionnaires personally administered to the staffs of the respective banks with a high response rate of $75 \%$. The structured questionnaire was administered to obtain relevant information from 
conveniently selected respondents within Lagos metropolis who showed interest in the subject matter. The questionnaire consisted of 20 questions in statement forms describing issues operationalised in the concept of corporate governance and bank distress as it relates to Nigerian banking industry. Responses were measured using Likert five point-scale of; strongly agree to strongly disagree. The research work was designed in such a way that data was generated from the questionnaires were personally administered to the staffs of the respective banks.

This study employed the Stratified Sampling technique. In Adebayo (2004), stratified sampling, is the population categorized into groups that are distinctly different from each other on relevant variables. Each group is called stratum (plural strata). In applying stratified sampling, we categorized the population and stratified using bank capital. Each group is called stratum (plural strata). In this study, the elements in a particular stratum are the same with respect to the relevant parameter (bank capital). The banks are grouped into stratum and were selected using simple random sampling supported by judgment sampling (non-probability) methods. These banks were selected using judgmental sampling technique in order to have a representation of the population. Four sample banks were selected and are made up of two old generation banks and two new generation banks. New generation banks came on board in Nigeria from 1989 because of the innovations they introduced. The sample size of this research work constitutes four Nigeria banks. They include Eko bank, Access bank (new) United Bank of Africa and First bank of Nigeria (old).

Krejcie \& Morgan (1970) in Amadi (2005) agrees with the sample as they proposed the population proportion of 0.05 as adequate to provide the maximum sample size required for generalization. To the best of the researcher's judgment, the banks make a good representation of the banking industry in Nigeria. The expert opinion was sought for in order to validate the content and the structure of the questionnaire during the pilot study. The method that was used in the presentation of data in this study is the Statistical Package for Social Sciences (SPSS) which contains all the necessary and important statistical technique for data analysis. For testing the hypothesis, correlation analysis which measures the degree of relationship between variables was used to analyze the result generated from the questionnaire. Correlation analysis is a technique used to assess the extent to which two sets of observations or series of data regarding a particular problem or situation can be regarded as positively or negatively related to each other by association. Correlation analysis helps in determining whether or not two sets of observation co-vary and as such help to determine whether there is any correlation between good corporate governance and distress in the Nigerian banking sector. Theoretically, two sets of data or observations are said to be correlated if there is evidence to believe that there is a positive or negative association in their magnitude and direction. The numerical method which entails using the coefficient of correlation and Karl Pearson's Product Moment Correlation is used because it is a measure of linear relationship between two variables $\mathrm{X}$ and $\mathrm{Y}$.

\subsection{DISCUSSION OF RESULTS}

\section{Hypothesis One}

$\mathrm{H}_{0}$ : There is no significant relationship between good corporate governance and prevention of bank distress

$\mathrm{H}_{1}$ : There is significant relationship between corporate governance and the prevention of bank distress.

Table 4-1: Pearson's correlation between corporate governance and bank distress Correlations

\begin{tabular}{|ll|l|l|}
\hline & & & \\
\hline Corporate Governance & Pearson Correlation & Corporate Governance & Prevention of Bank distress \\
& Sig. (2-tailed) & & .087 \\
& $\mathrm{~N}$ & 90 & .417 \\
Prevention of Bank distress & Pearson Correlation & .087 & 90 \\
& Sig. (2-tailed) & .417 & 1 \\
& N & 90 & 90 \\
\hline
\end{tabular}

Source: SPSS print out (March 2011)

Coefficient of determination

The coefficient of determination is given by the formula;

C.O. $D=r^{2} \times 100$

$=(0.087)^{2} \times 100$

$=0.7569 \times 100$

$=75.69 \%$

Where $\mathrm{r}=$ Pearson correlation 0.417 
Correlation is not significant at $42 \%$ because it is above $10 \%$

\section{Interpretation}

The relationship between corporate governance and prevention of bank distress does not have a significant correlation and the correlation coefficient derived from the analysis showed significance $=0.417$ which exceeds significance level of $10 \%$.

\section{Decision}

The outcome of the Pearson correlation ( $\mathrm{r}=0.087$, significance 0.417 ). It is with this regard that the null hypothesis will be accepted. This simply implies that corporate governance has no significant improvement on the prevention of bank distress.

\section{Hypothesis two}

$\mathrm{H}_{0}$ : There is no significant relationship between practice of good corporate governance and better performance of banks

$\mathrm{H}_{1}$ : there is a significant relationship between practice of good corporate governance and better performance of banks.

Table 4-2: Pearson's correlation between corporate governance and bank performance Correlations

\begin{tabular}{|ll|l|l|}
\hline & & Corporate Governance & Performance \\
\hline Corporate Governance & Pearson Correlation & 1 & $.304(* *)$ \\
& Sig. (2-tailed) & & .004 \\
& $\mathrm{~N}$ & 90 & 90 \\
Performance & Pearson Correlation & $.304(* *)$ & 1 \\
& Sig. (2-tailed) & .004 & 90 \\
& $\mathrm{~N}$ & 90 & \\
\hline
\end{tabular}

** Correlation is significant at the 0.01 level (2-tailed).

Source: SPSS print out (March 2011)

Interpretation

The correlation coefficient is .304 and the level of significance is $1 \%$

The coefficient is $.304 \times 100=30.4$ since $0.20 \leq \mathrm{r} \leq 0.50=$ moderate relationship, there is a moderate relationship between corporate governance and bank performance and it is significant at $1 \%$ level of significance.

\section{Decision}

From the table above, there is a positive relationship between corporate governance and bank performance at the level of significance at $1 \%$. Therefore we reject the null hypothesis $\left(\mathrm{H}_{0}\right)$ and accept the alternative $\left(\mathrm{H}_{1}\right)$. This simply implies that corporate governance has significantly improved the performance of the Nigerian banking sector.

\subsection{CONCLUSIONS AND RECOMMENDATIONS}

In particular, we know that bank distress in Nigeria and other economies have been caused in part, by excessive exposure concentration, directed lending, lending to connected parties and poor credit policy. To a large extent, such basic risk management failures reflect a break down in corporate governance. They reflect poor management of conflict of interest, inadequate understanding in the board room of key banking risks and poor oversight by boards of the mechanism for managing their banks, such as risk management system and internal audit arrangement. In some cases a lack of truly independent directors on the boards of banks was also a significant factor in weakening the effectiveness of boards. And these problems are compounded by poor quality financial disclosures and ineffective external audit. Adherence to corporate governance is the foundation for effective risk management.

It is evident that sound corporate governance is essential to the wellbeing of a bank and stakeholders, particularly its shareholders and creditors. Practice of corporate governance is not just a vital factor at the level of Individual Corporation; it is also a critical ingredient in curbing distress in banks, promoting and maintaining a sound financial system and stability which in turn ensures a robust economy. To this end, the federal government through the regulatory authority (i.e. central bank of Nigeria and security and exchange commission) has taken keen interest in reviewing and emphasizing the adherence to the year 2011 revised code of corporate governance in other to curb future bank distress in Nigeria.

\section{Recommendations}

Based on the theoretical and empirical findings in this study the following recommendations are therefore made: 
(1) Since corporate governance has no significant improvement on the prevention of bank distress; banks should be able to demonstrate that rigorous internal policies were in place and that procedures existed for identifying and managing conflicts of interest to avoid its adverse consequences on their customers and other stakeholders. Insider abuse, conflict of interest and widespread manipulations are at the heart of a nation's financial sector crisis, this crisis connived at or orchestrated by management and board, should be captured by internal and external auditors and regulators so as not to reach serious proportions.

(2) The study shows that corporate governance has significantly improved the performance of the Nigerian banking sector. Therefore, in addressing the role of corporate governance in curbing distress the central bank should review the fit and proper person's regime in other to ensure that only credible persons of impeccable financial, personal and professional character are allowed as major shareholders, directors and managers of banks. The central bank should also strengthen its on-site and off- site supervision functions in recognition of the need for an effective supervision of the banking sector.

(3) To ensure that there is a clear division between the chief executive officer and the managing directors, the Central Bank of Nigeria should enforce and continue to ensure compliance to the 10 years term limit for banks chiefs. Persons occupying these positions should be properly approved by the apex body i.e. central bank of Nigeria and such persons must be knowledgeable in business and financial matters with requisite experience in the banking field.

(4) The banks should establish committees /departments within their banks so as to oversee the management of risk and credit. This is also to forestall any potential risk and prevent the bank from any imminent or future distress.

(5) Regulatory authorities and other stakeholders in the Nigerian financial sector need to adopt a zero tolerance posture against cases of unsound corporate governance practices. This will ensure that the banks are well run and administered. Identifying, preventing and managing conflict of interest should be at a very heart of corporate governance.

(6) The central bank and relevant professional body such as Chartered Institute of Bankers of Nigeria (CIBN) should ensure that bank workers do not hold vital position in the banks but rather bankers who are proven competent after the completion of the relevant professional courses should be given full backing to operate.

\section{REFERENCES}

Adebayo, O.A. (2004): Understanding Statistics, JAS Publishing, Lagos P. 238

Ahmed, M. (2007): "Corporate Governance: A New Fad or an Important Development Prerequisite"? Paper Presented at the Management Express Forum of the British Council in Calabar 30 ${ }^{\text {th }}$ March 2007.

Al-Faki, M (2007): "The Incidence of inaccurate Corporate Financial Reporting in Nigeria Capital Market: the Role of Securities and Exchange Commission in Preventing Future Occurrences". www.sec.gov.ng Accessed 28 September, 2011.

Amadi V.L., (2005): “An Investigation into the Role of Private Sector in Nigeria Higher Institution: A Study of the University of Abuja", International Journal of Research in Education. Vol. 2 No 1\&2

Arunma, O. (2010): "Good Governance and Regulatory Leadership" Keynote Address by The Director General Securities and Exchange Commission at the International Conference www.sec.gov.ng, Extracted on $23^{\text {rd }}$ March 2011.

Babalola, A. (2010): “Corporate Governance Distress, Syndrome and Nigerian Banks”, http://papers.ssrn/s013/papers.cfm?abstract_1d=1662908, Extracted on $1^{\text {st }}$ February 2011.

Black, B.S; Jang, H. \& Kin, W. (2006): "Does Corporate Governance Predict Firms Market Values"? Evidence From Korea Journal of Law, Economics and Organization, 22 (2) 3-13

Central Bank of Nigeria, CBN (2006): "Code of Corporate Governance for Banks in Nigeria Post Consolidation", www.cenbank.org Accesses 30 October 2008.

Chiejina, A. (2009): "Ensuring Credibility and Corporate Governance in the Banking Industry", Business Day, Monday 24, August.

Claessens, S (2006): "Corporate Governance and Development”, The World Bank Research Observer, 2191$)$ 91-122

Donaldson, L and Davis, J.H (1994): "Boards and Company Performance: Research Challenges and Conventional Wisdom”, Corporate Governance an International Review, Volume 2, No 3, pp.151-160.

Elebuta, K (1999) "The role of External Auditors in Resolving Distress" This Day Newspaper $30^{\text {th }}$ May.

Etukodo, A. (2000): "Issues in Privatization and Restructuring in Sub-Saharan Africa-Interdepartmental Action Programme on Privatization, Restructuring and Economic Democracy Working Paper (IPPRED)", www.ilo.org Accessed 30 October 2011.

Federal Government of Nigeria: The Companies and Allied Matters Act 1990 (CAMA)

Federal Government of Nigeria: Bank and Other Financial Institutions Act 1991 (BOFIA). 
Habeeb, A. (2010): "Conceptual Framework for Corporate Governance in Nigeria Challenges and Panaceas". http://www.pmworldtoday.net , Extracted on $1^{\text {st }}$ February 2011.

Hennie van Greuning and Sonja Brajovic Bratabovic (2009): Analyzing Banking Risk: A Framework for Assessing Corporate Governance and Risk Management. The World Bank, Washington, D.C. pp 41-46.

Inyang, B.J (2004): Corporate Planning and Policy: Concepts and Application ( ${ }^{\text {st }}$ Edition) Merb Publishers, Calabar pp .2-4 Ivor, O. (2008) "Corporate Governance: An Appraisal of Disclosure in Nigerian Banks"

http://bizcovering.com/accounting/corporate-governance-an-appraisal-of-disclosure-in- Nigeria, Extracted on 19 September 2010.

Ogbechie, C and Koufopoulos, D.N (2007): "Corporate Governance Practices in Publicly Quoted Companies in Nigeria", International of Business Governance and Ethics, 3 (4), 350-381

Okeahalam, C.C and Akinboade, O.A (2003): "A Review of Corporate Governance in Africa: Literature, Issues and Challenges", Paper Prepared for the Global Corporate Governance Forum, 15 June 2003, pp 1-20 www.ifc.org Accessed 15 November, 2011

Okike, E.N.M (1995): "Corporate Audit Reporting and the Structure of the Market for Audit Services to Listed Companies in Nigeria: A longitudinal Study", A Research Report Submitted to the Research Committee of the Institute of Chartered Accountants of Nigeria (ICAN).

Okike, E.N.M (1998): "Voluntary Disclosure in Corporate Audit Reports: A Nigerian Case Study (1978-1989)", International Journal of Auditing, 2, 139-1666

Okike, E.N.M (1999): "A Longitudinal Analysis of the Quality of Audit Reporting on the Accounts of Listed Companies in Nigeria Following the Indigenization of Equity Capital (1978-1989)", Research in Accounting in Emerging Economies, Supplement 1, 255-286.

Okike, E.N.M (2007): “Corporate Governance in Nigeria: the Status Quo”, Corporate Governance, 15 (2), 173 193.

Okike, E.N.M (1995): "Corporate Audit Reporting and the Structure of the Market for Audit Services to Listed Companies in Nigeria: A longitudinal Study", A Research Report Submitted to the Research Committee of the Institute of Chartered Accountants of Nigeria (ICAN)

Organization of Economic Cooperation Department (OECD, 2004): "Principles of Corporate Governance", Revised April 2004, Originally issued June 1999,Quinn, D and Jones, T. (1995): “An Agency Morality view of Business Policy", Academy of Management Review, volume 20, no 1, pp 22-24.

Securities and Exchange Commission (SEC) of Nigeria (2003): "Code of Corporate Governance in Nigeria", www.sec.gov.ng Accessed 12 November 2011

Shah, S.M. Amir and Haq, Mirza, Irfan U (2007): "Corporate Governance and Firm Performance: Empirical Study on Cement Sector of Pakistan", Paper Presented in the Fourth International Business Research Conference on "Research for Difference" on January 14-15, BIAM Foundation, Dhaka, Bangladesh, pp 1-3.

Sani, A. (2010) "Distress in Nigerian banking industry: a critical of its nature and causes and extent", www.freewebs.com/bizadm/publication4.htm, Extracted on 19th September 2010.

Sanusi, J.O. (2002): "Promoting Good Corporate Governance Issues and Challenges" Keynote Address Delivered at the Annual Directors Seminar Organized by FITC, at Nicon-Hilton Hotel Abuja, http://www.cenbank.org/out/speeches. Extracted on 3rd October 2010.

Sanusi, J.O. (2003): "Balancing Stakeholders Interest: Issues and Challenges" Keynote Address Delivered at the Directors Seminar Organized by FITC, at Nicon-Hilton Hotel Abuja, http://www.cenbank.org/out/speeches, Extracted on 3rd October 2010.

Sanusi, L. (2010): "The Nigerian Banking Industry: What Went Wrong and The Way Forward", http://www.cenbank.org/out/speeches, Extracted on $3^{\text {rd }}$ October 2010.

Sanusi, J.O (2010). "Promoting Good Corporate Governance: Issues and Challenges", www.cenbank.org, Extracted on $19^{\text {th }}$ September 2010.

Solomon, J. (2007): Corporate Governance and Accountability, John Wiley and Sons Publishing Ltd, West Sussex, England pp131-140.

Templars Barristers and Solicitors 92006): Corporate Governance - New Corporate Mantr? www.templarslaw.com Accessed 12 November, 2011.

Unegbu, O.C.K. (2003): Corporate Governance in Banking and Other Financial Institution, Laws, Issues and Ethics, CIBN Press Ltd, Lagos pp 33-50.

Williamson, O.E (1996): The Mechanisms of Governance, Oxford University Press, New York, P

Wilson, 1 (2006): "Regulatory and Institutional Challenges of Corporate Governance in Nigeria Post Banking Consolidation", Nigeria Economic Summit Group (NESG) Economic Indicators, April-June 2006, 12 (2), 1-10 www.teplars-law.com

Wise Victoria and Mahboob Ali (2009): "Corporate Governance and Corporate Social Responsibility in Bangladesh with special reference to Commercial Banks", AIUB Business and Economic Working Paper Series 
pp. 1-3.

\section{BIOGRAPHY}

Dr. IKPEFAN, Ochei Ailemen graduated from University of Benin, Benin City in 1983/1984 and Obtained B.Sc (Hons) B.Sc Business Administration. In 1992, he obtained MBA (Finance) from University of Benin. He is a member of many professional and academic bodies. He is an Associate Member of the Chartered Institute of Banker of Nigeria (ACIB), Associate Member of the Institute of Chartered Accountant of Nigeria (ACA), Fellow of the Nigerian Institute of Management (FNIM) and has a Diploma in French from the French Language Centre, Benin City. He is currently a Senior lecturer of the Department of Banking \& Finance, Covenant University, Ota, Ogun State, Nigeria. Dr Ikpefan O.Ailemen is an accomplished academician who has published over forty articles to reputable journals both local and international. He is currently on the academic staff of Covenant University, Ota, Ogun State. His hobbies include reading and sports especially football. He is a retired Grade One Referee and now a match commissioner with the Nigeria (Football) Referee Association. He is married with children.

OJEKA,Stephen Obtained his First and Second degree in Accounting from Covenant University, Ota in 2006 and 2010 respectively. He is currently a lecturer with Covenant University Ota. He is member of Institute of Accountant of Nigeria (ICAN).He has published in both local and international journals. 
This academic article was published by The International Institute for Science, Technology and Education (IISTE). The IISTE is a pioneer in the Open Access Publishing service based in the U.S. and Europe. The aim of the institute is Accelerating Global Knowledge Sharing.

More information about the publisher can be found in the IISTE's homepage: http://www.iiste.org

\section{CALL FOR JOURNAL PAPERS}

The IISTE is currently hosting more than 30 peer-reviewed academic journals and collaborating with academic institutions around the world. There's no deadline for submission. Prospective authors of IISTE journals can find the submission instruction on the following page: http://www.iiste.org/journals/ The IISTE editorial team promises to the review and publish all the qualified submissions in a fast manner. All the journals articles are available online to the readers all over the world without financial, legal, or technical barriers other than those inseparable from gaining access to the internet itself. Printed version of the journals is also available upon request of readers and authors.

\section{MORE RESOURCES}

Book publication information: http://www.iiste.org/book/

Recent conferences: http://www.iiste.org/conference/

\section{IISTE Knowledge Sharing Partners}

EBSCO, Index Copernicus, Ulrich's Periodicals Directory, JournalTOCS, PKP Open Archives Harvester, Bielefeld Academic Search Engine, Elektronische Zeitschriftenbibliothek EZB, Open J-Gate, OCLC WorldCat, Universe Digtial Library, NewJour, Google Scholar

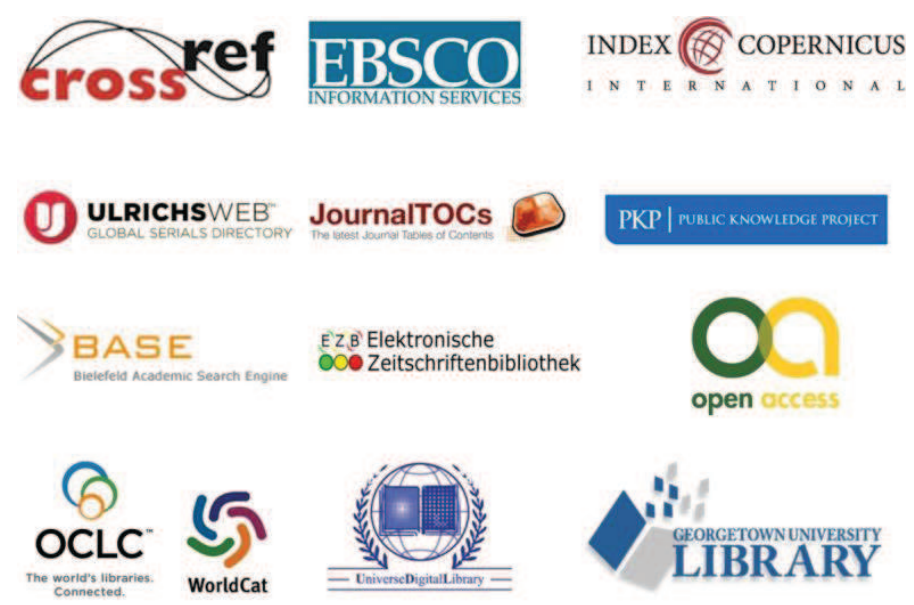

